\title{
Biochemical and physiological responses of soybean [Glycine max (L.) Merrill] to nickel toxicity
}

\author{
Andersom Milech Einhardt ${ }^{1}$ (D), Sandro Ferreira ${ }^{1}$ (D), Fabrício Ávila Rodrigues ${ }^{1, *}$ (D) \\ 1. Universidade Federal de Viçosa - Departamento de Fitopatologia - Viçosa (MG), Brazil. \\ Received: Apr. 10, 2020 | Accepted: Jan. 20, 2021 \\ Section Editor: Robson Di Piero \\ *Corresponding author: fabricio@ufv.br \\ How to cite: Einhardt, A. M., Ferreira, S., Rodrigues, F. A. (2021). Biochemical and physiological responses of soybean (Glycine max (L.) \\ Merrill) to nickel toxicity. Bragantia, 80, e1721. https://doi.org/10.1590/1678-4499.20200152
}

\begin{abstract}
Despite the crucial role of nickel (Ni) in the plant metabolism, small increases in its concentration can cause leaf tissues injury. This study identified the highest dose of Ni foliar-applied that does not cause toxicity to soybean plants. Plants were sprayed with five Ni doses $\left(0,30,60,120\right.$, and $\left.240 \mathrm{~g} \cdot \mathrm{ha}^{-1}\right)$. At 1,3 , and 5 days after spray (DAS), the malondialdehyde (MDA), superoxide $\left(\mathrm{O}_{2}^{-}\right)$, hydrogen peroxide $\left(\mathrm{H}_{2} \mathrm{O}_{2}\right)$, and photosynthetic pigments concentrations, antioxidant enzymes activities, and gas exchange and chlorophyll ( $\mathrm{Chl}$ ) $a$ fluorescence parameters were determined. Symptoms of Ni toxicity started at $120 \mathrm{~g} \cdot \mathrm{ha}^{-1} \mathrm{Ni}$ and intense foliar necrosis occurred at $3 \mathrm{DAS}$. The concentrations of $\mathrm{O}_{2}^{-}, \mathrm{H}_{2} \mathrm{O}_{2}$, and MDA were significantly higher by $49 \%$ at $3 \mathrm{DAS}, 47 \%$ at $3 \mathrm{DAS}$, and $19 \%$ at 5 DAS, respectively, for plants sprayed with $120 \mathrm{~g} \cdot \mathrm{ha}^{-1} \mathrm{Ni}$ and by $48 \%$ at $3 \mathrm{DAS}, 48 \%$ at 3 DAS and $18 \%$ at 5 DAS, respectively, for plants sprayed with $240 \mathrm{~g} \cdot \mathrm{ha}{ }^{-1} \mathrm{Ni}$. Higher antioxidant enzymes activities and lower $\mathrm{Chl} a$ and $\mathrm{Chl} b$ concentrations occurred for plants sprayed with either 120 and $240 \mathrm{~g} \cdot \mathrm{ha}-{ }^{-1}$ $\mathrm{Ni}$ compared to the other Ni doses. Decrease on energy destined to photochemical process [Y(II)] ( 8 and $8 \%$ at 5 DAS) and increase on the dissipation of energy by the nonregulated process [Y(NO)] (15 and 15\% at 5 DAS) occurred for plants sprayed with 120 and $240 \mathrm{~g} \cdot h \mathrm{a}^{-1}$ $\mathrm{Ni}$, respectively. The Ni doses above $120 \mathrm{~g} \cdot \mathrm{ha}^{-1}$ promoted oxidative stress to the plants and affected the functionality of their photosynthetic apparatus. Doses below $60 \mathrm{~g} \cdot \mathrm{ha}^{-1}$ had a low risk of toxicity to plants without causing any biochemical or physiological damage.
\end{abstract}

Key words: antioxidant enzymes, phytotoxicity, photosynthesis, plant nutrition, ROS.

Nickel (Ni) was the latest element to have its nutritional essentiality recognized for plants (Brown et al. 1987). It is a component of various enzymes, including glyoxalases (family I), hydrogenases, superoxide dismutase and urease (Chen et al. 2009). Inadequate Ni supply promotes changes in the plant metabolism, including processes related to nitrogen metabolism, such as amino acids, urea and ureides metabolisms (Rodríguez-Jiménez et al. 2016; Bai et al. 2006). Legumes that are dependent on N2 fixation (e.g., soybean) have their process impaired by Ni deficiency, because this element is an essential catalytic cofactor of [NiFe]-hydrogenase, an enzyme found in some symbiotic bacteria that recycles the $\mathrm{H}_{2}$ produced by a side reaction of nitrogenase in root nodules formed by the plant-bacteria association (Cammack 1995; Bagyinka 2014). Moreover, Ni has shown the potential to control soybean diseases, such as powdery mildew (Barcelos et al. 2018) and Asian soybean rust (Einhardt et al. 2020a; 2020b).

The concentration of Ni required by the majority of plant species is very low ( $0.01-10 \mathrm{mg} \cdot \mathrm{kg}^{-1} \mathrm{dry}$ weight), which is an extremely wide range compared to other elements (Gerendás et al. 1999). In soybeans, the critical concentration of Ni deficiency is between 0.02 and $0.04 \mathrm{mg} \cdot \mathrm{kg}^{-1} \mathrm{dry}$ weight (Eskew et al. 1984). Even though low Ni concentration is usually sufficient to avoid visual symptoms of deficiency, soybean plants without visual symptoms may suffer from its deficiency (Freitas et al. 2019). On the opposite side, soil contamination with excess Ni can lead to a toxic effect on plants. According to Chen et al. (2009), the interference with other essential metal ions and induction of oxidative stress are two indirect pathways of Ni toxicity in plants. Plants under conditions of Ni-excess show various responses and toxicity symptoms, including retardation of germination, inhibition of growth, reduction of yield, induction of leaf chlorosis and wilting, disruption of photosynthesis, inhibition of $\mathrm{CO}_{2}$ assimilation, as well as reductions in stomatal conductance 
(Chen et al. 2009; Reis et al. 2017). High concentrations of Ni can promote an increase in the accumulation of reactive oxygen species (ROS), which can cause damage to cell membranes (Chen et al. 2009).

Considering the pivotal role of $\mathrm{Ni}$ in the metabolism of soybean plants, including the increase of their resistance against diseases and the risk of its toxicity, this study aimed to identify the maximum $\mathrm{Ni}$ dose that could not cause toxicity to soybean leaf tissues by examining some alterations at the biochemical and physiological levels.

Soybean seeds from the cultivar TMG135, containing $0.54 \pm 0.03 \mu \mathrm{g}$ Ni per seed (extracted by the nitric-perchloric digestion method [Zasoski and Burau 1977] and determined by inductive coupled plasma optical emission spectrometry [ICP-OES]) were sown in sand washed with $\mathrm{HCl} 1 \mathrm{~N}$. Seven days after sowing, five seedlings were transplanted to each $5 \mathrm{~L}$ plastic pots and cultivated in hydroponic system containing nutrient solution of Hoagland and Arnon (1950) with aeration. The nutrient solution was changed every four days and the $\mathrm{pH}$ adjusted to 6.0 daily. Plants were kept in a greenhouse (temperature of $28 \pm 3^{\circ} \mathrm{C}$, relative humidity of $80 \pm 5 \%$ and natural radiation). Plants at the $\mathrm{V} 4$ growth stage (three trifoliate expanded leaves) were sprayed with solutions ( $9 \mathrm{~mL}$ per plant) of $\mathrm{NiSO}_{4} \cdot 6 \mathrm{H}_{2} \mathrm{O}$ at the concentrations of $0,74.6,149.2,298.4$ and $596.8 \mathrm{mg} \cdot \mathrm{L}^{-1}$, equivalent to $0,30,60,120$ and $240 \mathrm{~g} \cdot \mathrm{ha}^{-1} \mathrm{Ni}$, considering a plant density of 200,000 plants per hectare. For biochemical analysis, the first three trifoliate leaves of two plants from the replication of each treatment were collected at 1,3 and 5 days after spray (DAS). Leaf samples were collected in liquid nitrogen and stored at $-80^{\circ} \mathrm{C}$ until further analysis. Cellular oxidative damage was estimated based on the production of total 2-thiobarbituric acid reactive substances and expressed as equivalents of malondialdehyde (MDA) according to Hodges et al. (1999). The concentrations of superoxide $\left(\mathrm{O}_{2}^{-}\right)$and hydrogen peroxide $\left(\mathrm{H}_{2} \mathrm{O}_{2}\right)$ were quantified according to Chaitanya and Naithani (1994) and Debona et al. (2012), respectively. The activities of superoxide dismutase (SOD, EC 1.15.1.1), catalase (CAT, EC 1.11.1.6), and ascorbate peroxidase (APX, EC 1.11.1.1) were determined according to the methodologies described by Debona et al. (2012). The gas exchange and chlorophyll (Chl) $a$ fluorescence parameters, as well as the concentration of photosynthetic pigments, were evaluated on the second trifoliate leaf of each plant at 1, 3, and 5 DAS. The photosynthetic pigments of six leaf-discs $\left(0.8 \mathrm{~cm}^{3}\right.$ each) were extracted with dimethyl sulfoxide saturated with calcium carbonate (Santos et al. 2008). The concentrations of $\mathrm{Chl} a, \mathrm{Chl} b$ and carotenoids were calculated based on the absorbance at 480, 649 and $665 \mathrm{~nm}$ (Sumanta et al. 2014). The Chl $a$ fluorescence parameters maximum photosystem II quantum efficiency $\left(F_{\mathrm{v}} / F_{\mathrm{m}}\right)$, photochemical yield [Y(II)], yield for dissipation by down-regulation [Y(NPQ)], yield for other nonphotochemical (nonregulated) losses $[\mathrm{Y}(\mathrm{NO})]$ and apparent electron transport rate (ETR) were obtained by using the Imaging-PAM image fluorometer and the Imaging Win software MAXI version (Heinz Walz GmbH, Effeltrich, Germany) following the procedures described by Fagundes-Nacarath et al. (2018) fixing in $5 \mathrm{~min}$ the time of actinic photon irradiance to obtain the steady-state fluorescence yield. The gas exchange parameters rate of net $\mathrm{CO}_{2}$ assimilation $(A)$, stomatal conductance to water vapor $\left(g_{s}\right)$, transpiration rate $(E)$ and internal $\mathrm{CO}_{2}$ concentration $\left(C_{\mathrm{i}}\right)$ were determined in the lateral leaflet of the second trifoliate leaf between 09:00 and 12:00 h, when $A$ was at its maximum, under artificial and saturating photon irradiance $\left(1200 \mu \mathrm{mol} \cdot \mathrm{m}^{-2} \cdot \mathrm{s}^{-1}\right)$ and an external $\mathrm{CO}_{2}$ concentration of $400 \mu \mathrm{mol} \cdot \mathrm{mol}^{-1}$ using a portable open-system infrared gas analyzer (LI-6400, LI-COR Inc., Lincoln, NE, USA). All measurements were performed by setting the block temperature at $25^{\circ} \mathrm{C}$.

The experiment was arranged in a completely randomized design with five treatments (control [plants sprayed with water] and plants sprayed with 30,60, 120 and $240 \mathrm{~g} \cdot \mathrm{ha}^{-1} \mathrm{Ni}$ ) with four replications. Each experimental unit consisted of a plastic pot containing five plants. Data from the variables and parameters evaluated were checked for normality and homogeneity of variance and then submitted to analysis of variance. Means of treatments were compared by Tukey's test $(\mathrm{p} \leq 0.05)$ by using the Minitab software v.18.

No symptoms of $\mathrm{Ni}$ toxicity were reported from plants sprayed with doses up to $60 \mathrm{~g} \cdot \mathrm{ha}^{-1} \mathrm{Ni}$ (Fig. 1a-c). Irrespective of the evaluation time, soybean plants exhibited symptoms of Ni toxicity starting at $120 \mathrm{~g} \cdot \mathrm{ha}^{-1} \mathrm{Ni}$. Necrotic areas were observed on

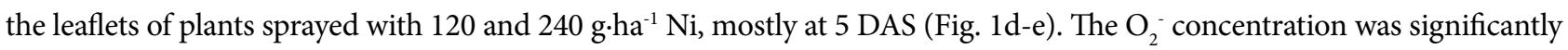
higher by 49 and $48 \%$, respectively, for plants sprayed with 120 and $240 \mathrm{~g} \cdot \mathrm{ha}^{-1} \mathrm{Ni}$ at $3 \mathrm{DAS}$ and by $42 \%$ for plants sprayed with 240 g.ha- ${ }^{-1} \mathrm{Ni}$ in comparison to that plants sprayed with water (Fig. 2a). At $3 \mathrm{DAS}, \mathrm{H}_{2} \mathrm{O}_{2}$ concentration was higher by 47 and $48 \%$, respectively, for plants sprayed with 120 and $240 \mathrm{~g} \cdot \mathrm{ha}^{-1} \mathrm{Ni}$ in comparison to plants sprayed with water (Fig. 2b). The MDA concentration at 5 DAS was higher by 19 and 18\%, respectively, for plants sprayed with 120 and 240 g.ha- ${ }^{-1} \mathrm{Ni}$ in comparison to plants sprayed with water (Fig. 2c). Superoxide dismutase activity significantly increased at 3 DAS by 57 and $54 \%$ for plants sprayed with 120 and $240 \mathrm{~g} \cdot \mathrm{ha}^{-1} \mathrm{Ni}$, respectively, and at 5 DAS by $37 \%$ for plants sprayed with $120 \mathrm{~g} \cdot \mathrm{ha}^{-1} \mathrm{Ni}$ in comparison to 
plants sprayed with water (Fig. 2d). Catalase activity significantly increased at 1 DAS by 26 and $25 \%$ for plants sprayed with 120 and $240 \mathrm{~g} \cdot \mathrm{ha}^{-1} \mathrm{Ni}$, respectively, and at $3 \mathrm{DAS}$ by $38 \%$ for plants sprayed with $240 \mathrm{~g} \cdot \mathrm{ha}^{-1} \mathrm{Ni}$ in comparison to plants sprayed with water (Fig. 2e). Ascorbate peroxidase activity significantly increased at 3 DAS by 30 and $32 \%$ and at 5 DAS by 32 and $31 \%$ for plants sprayed with 120 and $240 \mathrm{~g} \cdot \mathrm{ha}^{-1} \mathrm{Ni}$, respectively, in comparison to that plants sprayed with water (Fig. 2f). Irrespective of the evaluation time, the $\mathrm{Chl} a, \mathrm{Chl} b$, and $\mathrm{Chl} a+b$ concentrations decreased for plants sprayed with 120 and $240 \mathrm{~g} \cdot \mathrm{ha}^{-1} \mathrm{Ni}$, except for Chl $b$ at 1 DAS for the dose of $120 \mathrm{~g} \cdot \mathrm{ha}^{-1} \mathrm{Ni}$ (Fig. 3a-c). Carotenoid concentration decreased by 19 and

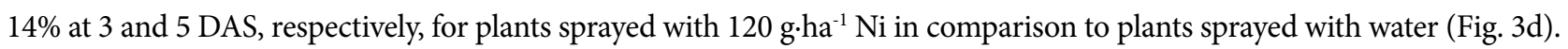

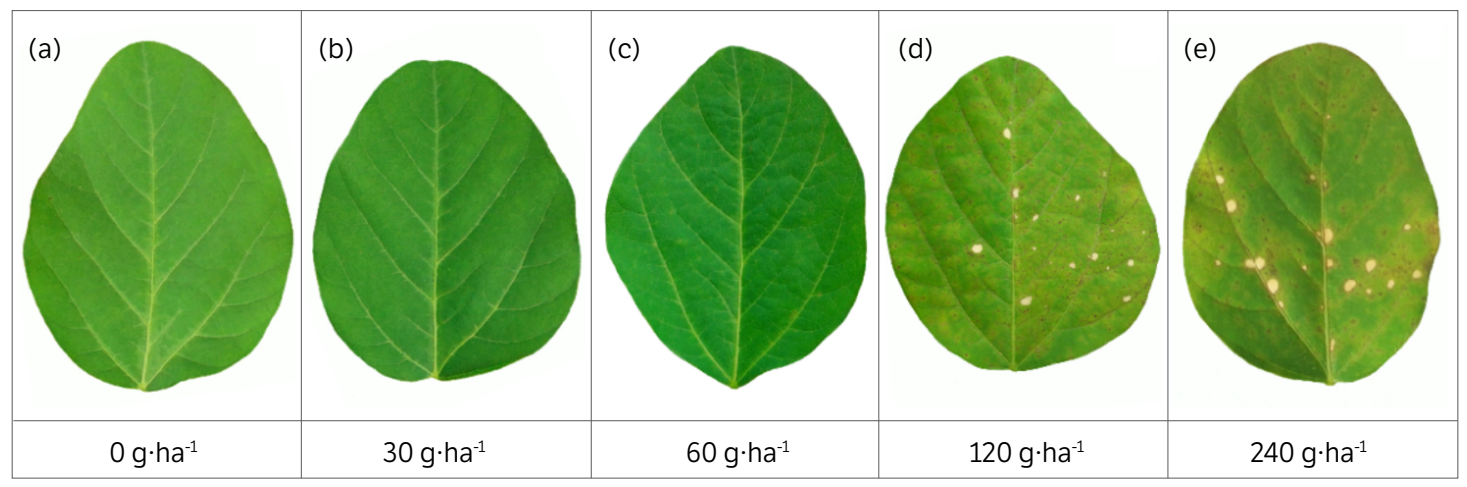

Figure 1. Leaflets from soybean plants at 5 days after being sprayed with water ( 0 ) or with solutions containing $30,60,120$ and $240 \mathrm{~g} \cdot \mathrm{ha}^{-1} \mathrm{Ni}$. Doses above $120 \mathrm{~g} \cdot \mathrm{ha}^{-1}$ resulted in necrotic areas in the sprayed leaflets.

(a)

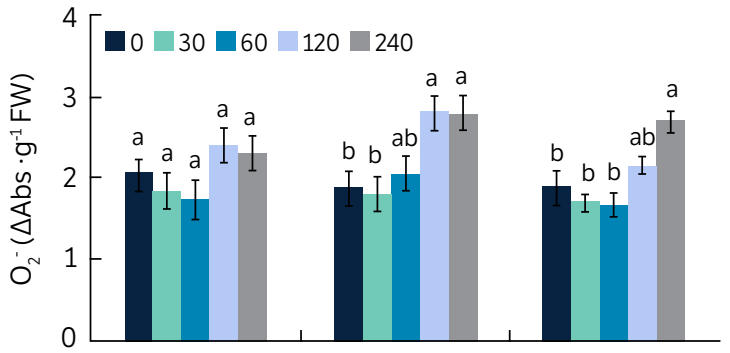

(c)

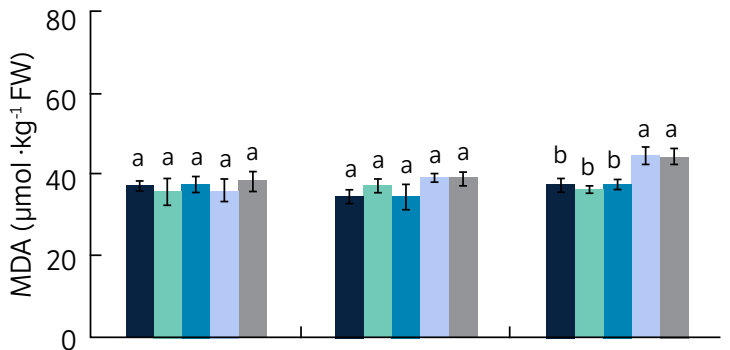

(e)

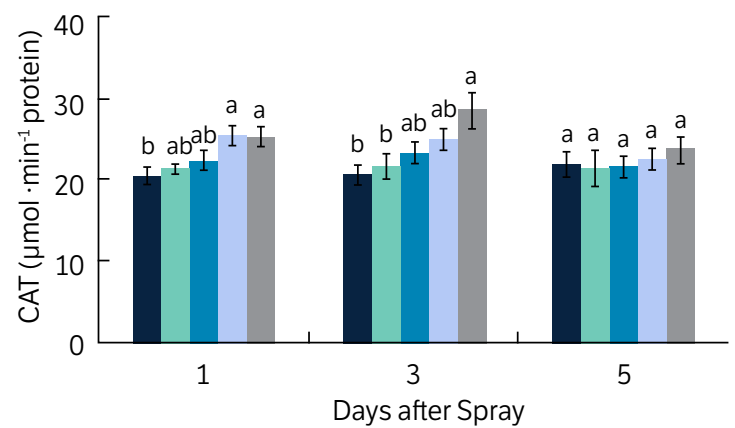

(b)

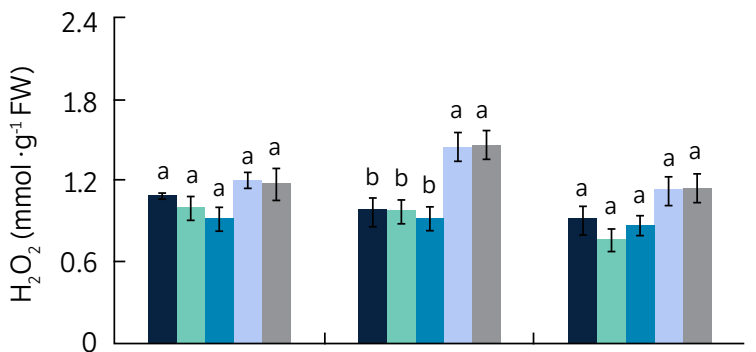

(d)

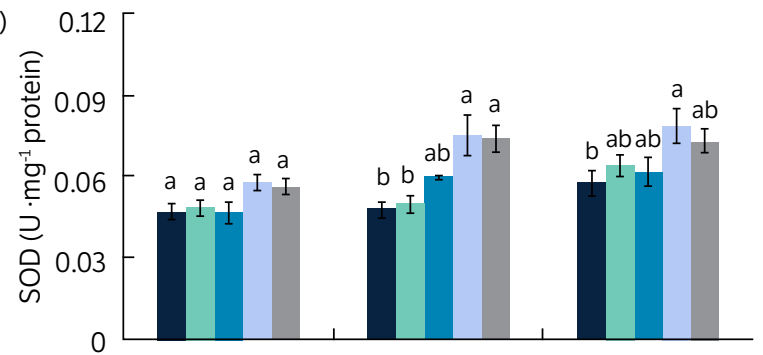

(f)

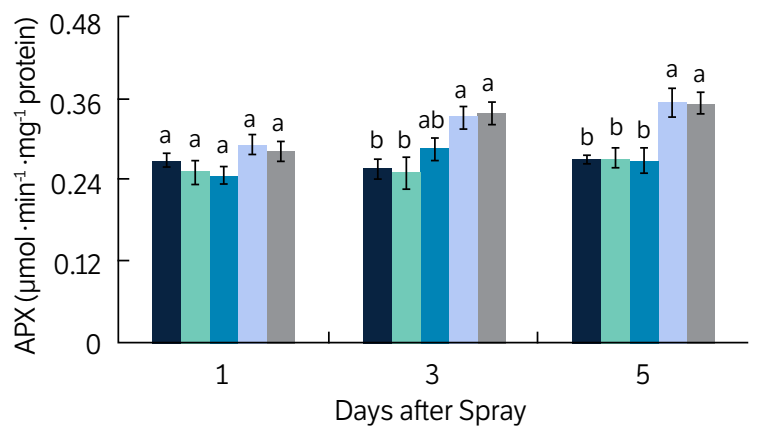

Figure 2. Concentrations of superoxide radical $\left(\mathrm{O}_{2}^{-}\right)(a), \mathrm{H}_{2} \mathrm{O}_{2}(b)$ and $M D A(c)$, as well as activities of SOD (d), CAT (e) and APX ( $f$ ) determined on the leaves of soybean plants sprayed with water (0) or with solutions of $30,60,120$ and $240 \mathrm{~g} \cdot \mathrm{ha}^{-1} \mathrm{Ni}$. Means for each treatment followed by different letters are significantly different $(p \leq 0.05)$ according to Tukey's test. $F W=$ fresh weight. Bars represent the standard error of the means. $n=4$. 
(a)

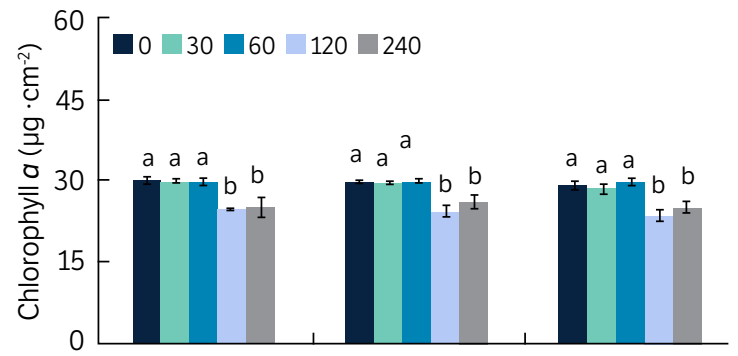

(c)

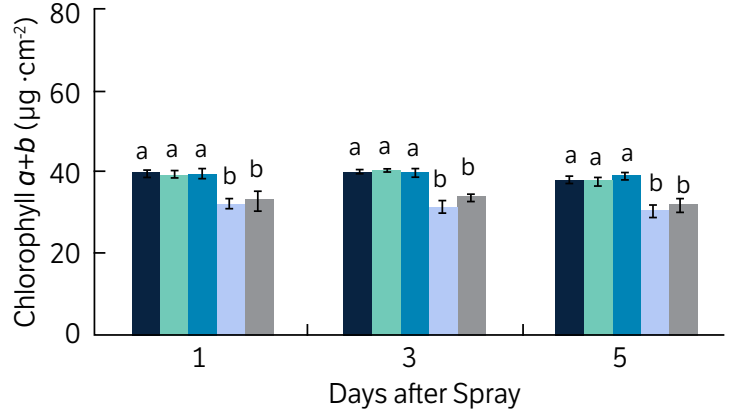

(b)

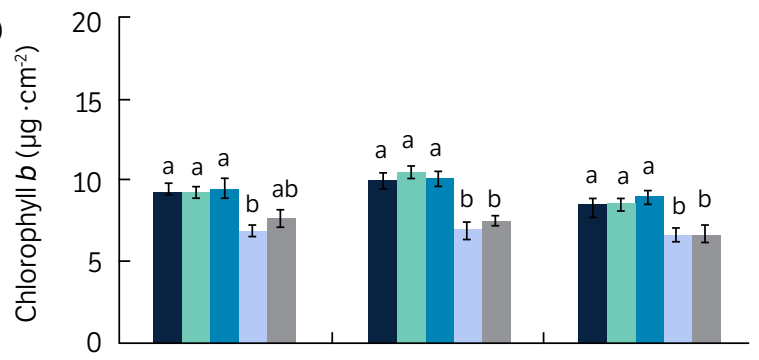

(d)

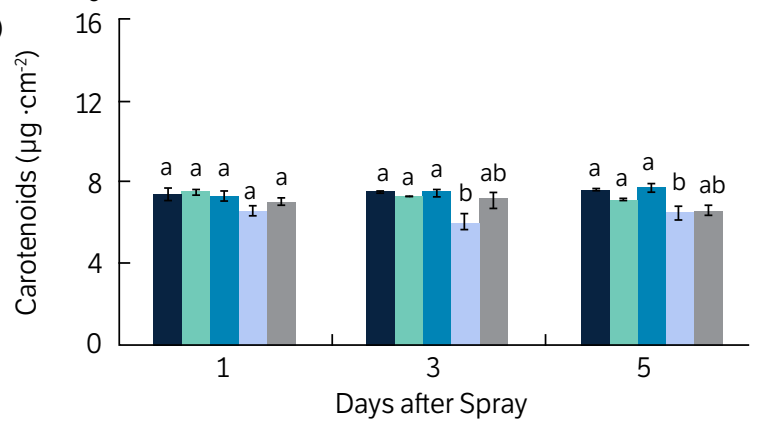

Figure 3. Concentrations of Chl $a(a), C h l b(b)$, total Chl (Chl $a+b)(c)$ and carotenoids (d) determined in the leaves of soybean plants sprayed with water (0) or with solutions of $30,60,120$ and $240 \mathrm{~g} \cdot \mathrm{ha}^{-1} \mathrm{Ni}$. Means for each treatment followed by different letters are significantly different ( $\mathrm{p} \leq 0.05$ ) according to Tukey's test. Bars represent the standard error of the means. $n=4$.

Images of Chl $a$ fluorescence on the leaflets obtained from plants sprayed with water or sprayed with 30 and 60 g.ha- ${ }^{-1}$ $\mathrm{Ni}$ did not show any difference between them regarding color patterns for the parameters maximum photosystem II $F_{\mathrm{v}} / F_{\mathrm{m}}$, $\mathrm{Y}(\mathrm{II}), \mathrm{Y}(\mathrm{NPQ})$ and $\mathrm{Y}(\mathrm{NO})$ (Fig. 4). Alterations in the images of Chl $a$ fluorescence parameters were observed on the leaflets of plants sprayed with 120 and $240 \mathrm{~g} \cdot \mathrm{ha}^{-1} \mathrm{Ni}$ in comparison to leaflets of plants sprayed with water (Fig. 4). The $F_{\mathrm{v}} / F_{\mathrm{m}}$ was significantly lower by 8 and $9 \%$ at 1 DAS, by 8 and $9 \%$ at 3 DAS and by 8 and $8 \%$ at 5 DAS for plants sprayed with 120 and $240 \mathrm{~g} \cdot \mathrm{ha}^{-1} \mathrm{Ni}$, respectively, in comparison to plants sprayed with water (Fig. $\left.5 \mathrm{a}\right)$. Similarly to $F_{\mathrm{v}} / F_{\mathrm{m}}, \mathrm{Y}$ (II) significantly decreased by 6 and $7 \%$ at 1 DAS, 8 and $8 \%$ at 3 DAS and 8 and $8 \%$ at 5 DAS, respectively, for plants sprayed with 120 and 240 g.ha ${ }^{-1}$ $\mathrm{Ni}$ in comparison to plants sprayed with water (Fig. 5b). No significant difference was observed for Y(NPQ) among the treatments (Fig. 5c). Regarding Y(NO), there were significant increases of 8 and 7\% at 1 DAS, 12 and 14\% at 3 DAS and 15 and $15 \%$ at 5 DAS, respectively, for plants sprayed with 120 and $240 \mathrm{~g} \cdot \mathrm{ha}^{-1} \mathrm{Ni}$ in comparison to plants sprayed with water (Fig. 5d). Electron transport rate was significantly lower by 10 and $11 \%$ at 1 DAS, 10 and $11 \%$ at 3 DAS and 9 and $10 \%$ at 5 DAS, respectively, for plants sprayed with 120 and $240 \mathrm{~g} \cdot \mathrm{ha}^{-1} \mathrm{Ni}$ in comparison to plants sprayed with water (Fig. 5e).
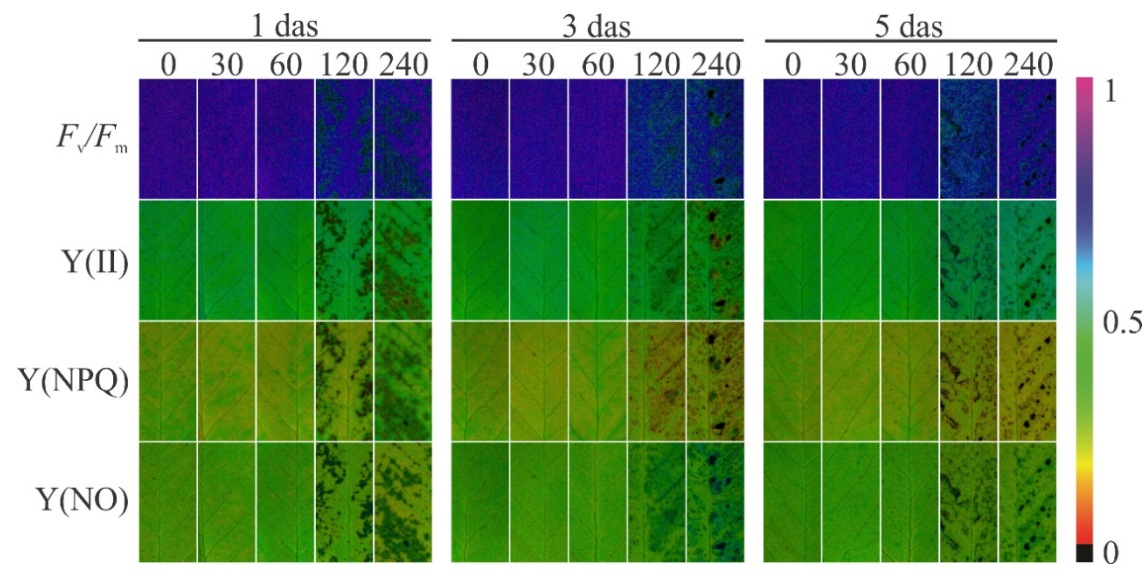

Figure 4. Images of the Chl a fluorescence parameters: maximum photochemical efficiency of photosystem II (PSII) $\left(F_{v} / F_{m}\right)$, effective yield of PSII [Y(II)], yield for dissipation by down-regulation energy [Y(NPQ)] and yield for other nonphotochemical (nonregulated) losses [Y(NO)] from leaflets of soybean plants sprayed with water (0) or with solutions of $30,60,120$ and $240 \mathrm{~g} \cdot \mathrm{ha} \mathrm{H}^{-1} \mathrm{Ni}$. das $=$ days after spray. 
(a)

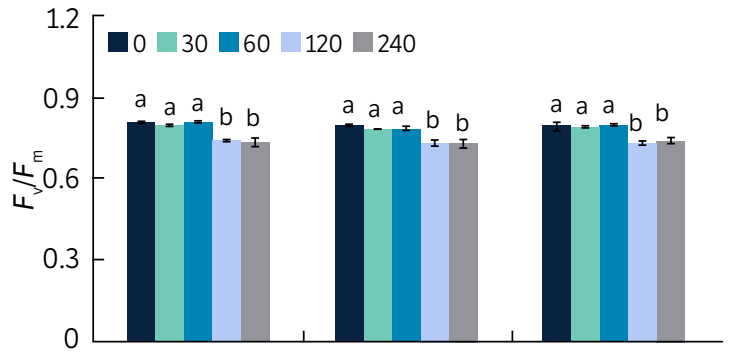

(c)

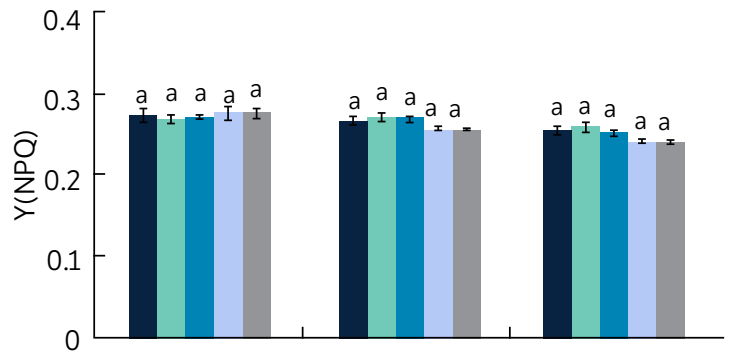

(e)

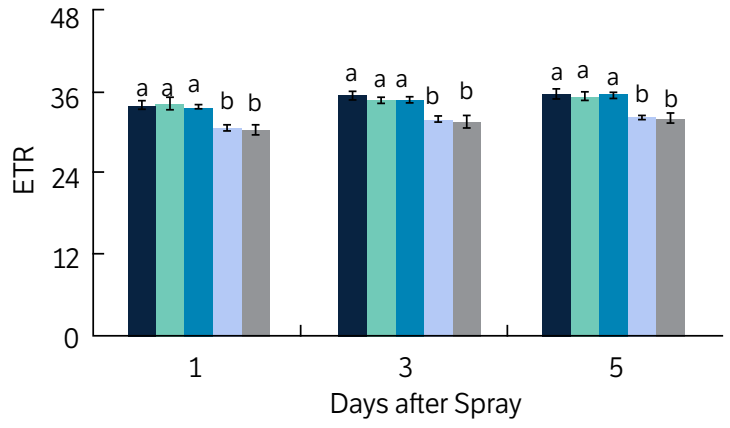

(b)

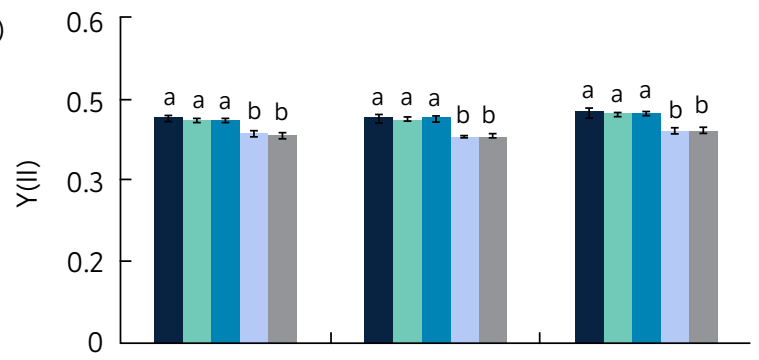

(d)

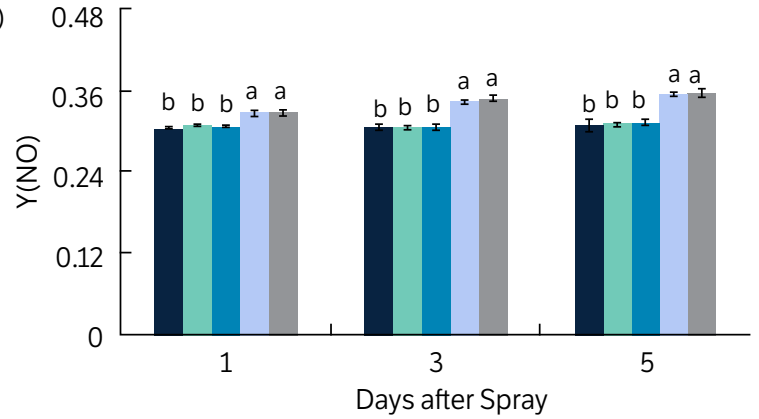

Figure 5. Chlorophyll a parameters: maximum photosystem II quantum efficiency $\left(F_{V} / F_{m}\right)(a)$, photochemical yield [Y(II)] (b), yield for dissipation by down-regulation [Y(NPQ)] (c), yield for other nonphotochemical (nonregulated) losses [Y(NO)] (d) and apparent ETR (e) determined in the leaflets of soybean plants sprayed with water (0) or with solutions of $30,60,120$ and $240 \mathrm{~g} \cdot \mathrm{ha}^{-1} \mathrm{Ni}$. Means for each treatment followed by different letters are significantly different $(p \leq 0.05)$ according to Tukey's test. The bars represent the standard error of the means. $n=4$.

Mainly, after 3 DAS, there were decreases for $A, g_{\mathrm{s}}$ and $E$ values and increase of $C_{\mathrm{i}}$ values for plants sprayed with 120 and $240 \mathrm{~g} \cdot \mathrm{ha}^{-1} \mathrm{Ni}$ in comparison to plants sprayed with water or sprayed with 30 and $60 \mathrm{~g} \cdot \mathrm{ha}^{-1} \mathrm{Ni}$ (Fig. 6A-D). Net $\mathrm{CO}_{2}$ assimilation values were lower by 21 and $18 \%$ at 3 DAS and by 19 and $17 \%$ at 5 DAS, respectively, for plants sprayed with 120 and $240 \mathrm{~g} \cdot \mathrm{ha}^{-1} \mathrm{Ni}$ in comparison to plants sprayed with water (Fig. 6a). Regarding $g_{s^{\prime}}$, there were significant decreases of 18 and $20 \%$ at 3 DAS and 27 and $26 \%$ at 5 DAS, respectively, for plants sprayed with 120 and 240 g.ha ${ }^{-1} \mathrm{Ni}$ in comparison to plants sprayed with water (Fig. 6b). Internal $\mathrm{CO}_{2}$ concentration values were higher by 8 and $8 \%$ at 3 DAS and by 8 and $9 \%$ at 5 DAS, respectively, for plants sprayed with 120 and $240 \mathrm{~g} \cdot \mathrm{ha}^{-1} \mathrm{Ni}$ in comparison to plants sprayed with water (Fig. 6c). The $E$ values were lower by 11 and $11 \%$ at 3 DAS and by 21 and $19 \%$ at 5 DAS, respectively, for plants sprayed with 120 and 240 g.ha- ${ }^{-1} \mathrm{Ni}$ in comparison to plants sprayed with water (Fig. 6d).

The results of the present study demonstrated that the foliar spray of $\mathrm{Ni}$ at doses up to $60 \mathrm{~g} \cdot \mathrm{ha}^{-1}$ was no toxic while doses above $120 \mathrm{~g} \cdot \mathrm{ha}^{-1}$ caused oxidative stress and damage to the photosynthetic apparatus of soybean leaf tissues. Plants sprayed with doses above $120 \mathrm{~g} \cdot \mathrm{ha}^{-1} \mathrm{Ni}$ presented chlorosis of leaves followed by tissue necrosis corroborating with the symptoms of Ni toxicity reported by Gajewska et al. (2006) and Antonkiewicz et al. (2016). The ROS are continuously produced in plant tissues as byproducts of the metabolic process (Dat et al. 2000). However, abiotic and biotic stresses in plants promote overproduction and accumulation of $\mathrm{ROS}$. The $\mathrm{O}_{2}{ }^{-}$and $\mathrm{H}_{2} \mathrm{O}_{2}$ are two moderate $\mathrm{ROS}$ and may be converted to hydroxyl $(\mathrm{OH})$ and hydroperoxyl radicals $\left(\mathrm{HO}_{2}^{-}\right)$causing cellular damage by lipid peroxidation (Demidchik 2015; Zhang et al. 2010). The increase on $\mathrm{O}_{2}^{-}$and $\mathrm{H}_{2} \mathrm{O}_{2}$ concentrations associated with the highest MDA concentration in plants supplied with 120 and 
$240 \mathrm{~g} \cdot \mathrm{ha}^{-1} \mathrm{Ni}$ indicated that these doses caused oxidative stress in the leaves resulting in lipid peroxidation. Moreover, the increased antioxidant enzyme activities were not sufficient to detoxify the ROS on the cells of plant tissues sprayed with 120 and $240 \mathrm{~g} \cdot \mathrm{ha}^{-1} \mathrm{Ni}$. Similarly, the major cause of Ni toxicity in the roots of grapevine (Pavlovkin et al. 2016) and in the leaves of wheat (Gajewska and Skłodowska 2007) was the oxidative stress resulting from an imbalance in the generation and or removal of ROS.
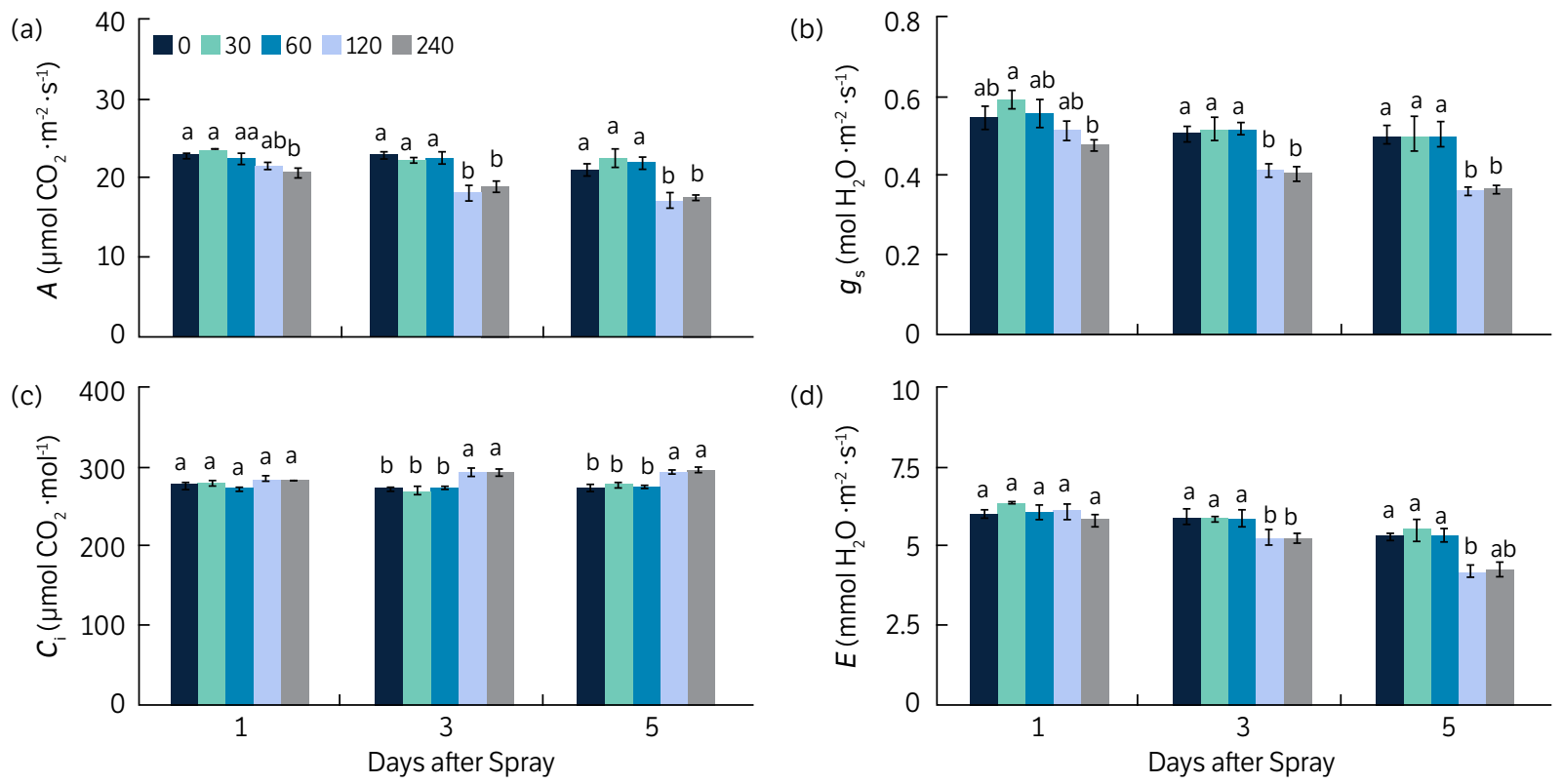

Figure 6. Leaf gas exchange parameters: rate of $A(a), g_{s}(b), C_{i}(c)$ and transpiration rate $(E)(d)$ determined in the leaflets of soybean plants sprayed with water $(0)$ or with solutions of $30,60,120$ and $240 \mathrm{~g} \cdot \mathrm{ha}^{-1} \mathrm{Ni}$. Means for each treatment followed by different letters are significantly different $(p \leq 0.05$ ) according to Tukey's test. The bars represent the standard error of the means. $n=4$.

The Ni does not generate ROS directly because it is not a redox-active metal (Chen et al. 2009). However, Ni interferes indirectly with several antioxidant enzymes, increasing or decreasing their activities (Baccouch et al. 1998; Gajewska and Skłodowska 2005). In the present study, the effect of high doses of Ni, increasing the accumulation of ROS, cannot be associated with a decrease in the activity of antioxidant enzymes. However, it is reasonable to relate the increase in ROS with the toxic effect of Ni on photosynthesis. Several indirect and direct paths are known, which lead to nonspecific metal inhibition of photosynthesis (Yusuf et al. 2011). The Ni excess damages the structure of thylakoid membranes and the structure of grana (Szalontai et al. 1999; Molas 2002), reducing the size of grana and increasing the number of nonappressed lamellae (Molas 1997). In fact, in the present study, high doses of $\mathrm{Ni}\left(120\right.$ and $\left.240 \mathrm{~g} \cdot \mathrm{ha}^{-1}\right)$ caused damage to the photosynthetic apparatus based on the low values of $F_{\mathrm{v}} / F_{\mathrm{m}}, \mathrm{Y}(\mathrm{II})$ and ETR and high $\mathrm{Y}(\mathrm{NO})$ values. An increase on the dissipation of energy by nonregulated process $[\mathrm{Y}(\mathrm{NO})]$ generally leads to an increase in ROS production that may have damaged the photosystems and other cellular constituents (Huang et al. 2018).

Distinctly from what was reported by Barcelos et al. (2017), we did not observe an increase on the concentration of photosynthetic pigments in the leaves of plants sprayed with nontoxic Ni concentrations in comparison to plants sprayed with water. These results were distinct probably due to the early plant growth stage evaluated in this study and the advanced plant growth stage reported by Barcelos et al. (2017). Considering the low Ni concentration demanded by plants, it is plausible to take into account that the Ni content in the seeds was sufficient to supply the plants demand at their growth stage evaluated with no effect on the synthesis of photosynthetic pigments. The decreases on Chl concentrations in the leaves of plants sprayed with toxic Ni doses (above $120 \mathrm{~g} \cdot \mathrm{ha}^{-1} \mathrm{Ni}$ ) are in agreement with the findings of Gopal et al. (2002), Gajewska et al. (2006) and Freitas et al. (2019) and can be attributed to disturbances in the synthesis of pigments (Stobart et al. 1985), as well as an increase on their degradation (Somashekaraiah et al. 1992). 
The limitations in the capacity of the photosynthetic apparatus to capture light and direct energy to photochemical process associated with limitation at stomatal conductance level on leaves of plants sprayed with 120 and $240 \mathrm{~g} \cdot \mathrm{ha}^{-1} \mathrm{Ni}$ resulted in a decrease on the capacity to process $\mathrm{CO}_{2}$. Plant leaf tissues exposed to heavy metals frequently decrease the stomatal aperture (Rucińska-Sobkowiak 2016). Reduction in stomatal conductance in leaves of soybean plants under Ni stress was observed by Reis et al. (2017). Rauser and Dumbroff (1981) reported that leaf tissues of common bean plants treated with Ni showed an increased level of abscisic acid, which is known to cause stomatal closure. Decreased stomatal conductance, associated with the limitations of light capture and use of its energy, already mentioned, may explain the increased $C_{\mathrm{i}}$ values observed for plants sprayed whit 120 and $240 \mathrm{~g} \cdot \mathrm{ha}^{-1} \mathrm{Ni}$ and probably not associated with biochemical limitations.

In conclusion, the spray of $\mathrm{Ni}$ doses above $120 \mathrm{~g} \cdot \mathrm{ha}^{-1}$ promoted oxidative stress on the leaf tissues of soybean plants and affected the functionality of their photosynthetic apparatus. The Ni doses below $60 \mathrm{~g} \cdot \mathrm{ha}^{-1}$ had a low risk to cause toxicity to soybean plants considering the absence of biochemical or physiological damage. It is imperative to consider that $\mathrm{Ni}$ concentration supplied by the soil when plants are grown in the field may decrease the threshold line of toxicity at lower levels than what is reported in the present study.

\section{AUTHORS' CONTRIBUTION}

Conceptualization: Einhardt A. M., Ferreira S., and Rodrigues F. A.; Methodology: Einhardt A. M., Ferreira S., and Rodrigues F. A.; Investigation: Einhardt A. M. and Ferreira S.; Writing - Original Draft: Einhardt A. M. and Ferreira S.; Writing - Review and Editing: Rodrigues F. A.; Funding Acquisition: Rodrigues F. A.; Resources: Rodrigues F. A.; Supervision: Rodrigues F. A.

\section{DATA AVAILABILITY STATEMENT}

Data will be available upon request.

\section{FUNDING}

Conselho Nacional de Desenvolvimento Científico e Tecnológico

[https://doi.org/10.13039/501100003593]

Fundação de Amparo à Pesquisa do Estado de Minas Gerais

[https://doi.org/10.13039/501100004901]

Coordenação de Aperfeiçoamento de Pessoal de Nível Superior

[https://doi.org/10.13039/501100002322]

Finance Code 001

\section{ACKNOWLEDGMENTS}

Prof. Rodrigues thanks to the Conselho Nacional de Desenvolvimento Científico e Tecnológico (CNPq) for his fellowship. 


\section{REFERENCES}

Antonkiewicz, J., Jasiewicz, C., Koncewicz-Baran, M. and Sendor, R. (2016). Nickel bioaccumulation by the chosen plant species. Acta Physiologiae Plantarum, 38, 40. https://doi.org/10.1007/s11738-016-2062-5

Baccouch, S., Chaoui, A. and Ferjani, E. E. (1998). Nickel-induced oxidative damage and antioxidant responses in Zea mays shoots. Plant Physiology and Biochemistry, 36, 689-694. https://doi.org/10.1016/S0981-9428(98)80018-1

Bagyinka, C. (2014). How does the ([NiFe]) hydrogenase enzyme work? International Journal of Hydrogen Energy, $39,18521-18532$. https://doi.org/10.1016/j.ijhydene.2014.07.009

Bai, C., Reilly, C. C. and Wood, B. W. (2006). Nickel Deficiency Disrupts Metabolism of Ureides, Amino Acids, and Organic Acids of Young Pecan Foliage. Plant Physiology, 140, 433-443. https://doi.org/10.1104/pp.105.072983

Barcelos, J. P. Q., Osório, C. R. W. S., Leal, A. J. F., Alves, C. Z., Santos, E. F., Reis, H. P. G. and Reis, A. R. (2017). Effects of foliar nickel (Ni) application on mineral nutrition status, urease activity and physiological quality of soybean seeds. Australian Journal of Crop Science, 11, 184. https://doi.org/10.21475/ajcs.17.11.02.p240

Barcelos, J. P. Q., Reis, H. P. G., Godoy C.V., Gratão, P. L., Furlani Junior, E., Putti, F. F., Campos, M. and Reis, A. R. (2018). Impact of foliar nickel application increase urease activity enhances antioxidant metabolism, and control powdery mildew (Microsphaera diffusa) in soybean plants. Plant Pathology 67, 1502-1513. https://doi.org/10.1111/ppa.12871

Brown, P. H., Welch, R. M. and Cary, E. E. (1987). Nickel: A Micronutrient Essential for Higher Plants. Plant Physiology, 85, 801-803. https:// doi.org/10.1104/pp.85.3.801

Cammack, R. (1995). Splitting molecular hydrogen. Nature, 373, 556-557. https://doi.org/10.1038/373556a0

Chaitanya, K. S. K. and Naithani, S. C. (1994). Role of superoxide, lipid peroxidation and superoxide dismutase in membrane perturbation during loss of viability in seeds of Shorea robusta Gaertn.f. New Phytologist Foundation, 126, 623-627. https://doi.org/10.1111/j.1469-8137.1994. tb02957.x

Chen, C., Huang, D. and Liu, J. (2009). Functions and Toxicity of Nickel in Plants: Recent Advances and Future Prospects. CLEAN - Soil, Air, Water, 37, 304-313. https://doi.org/10.1002/clen.200800199

Dat, J., Vandenabeele, S., Vranova, E., Van Montagu, M. and Inze, D. and Van Breusegem, F. (2000). Dual action of active oxygen species during plant stress responses. Cellular and Molecular Life Sciences, 57, 779-795. https://doi.org/10.1007/s000180050041

Debona, D., Rodrigues, F. A., Rios, J. A. and Nascimento, K. J. T. (2012). Biochemical Changes in the Leaves of Wheat Plants Infected by Pyricularia oryzae. Phytopathology, 102, 1121-1129. https://doi.org/10.1094/PHYTO-06-12-0125-R

Demidchik, V. (2015). Mechanisms of oxidative stress in plants: From classical chemistry to cell biology. Environmental and Experimental Botany, 109, 212-228. https://doi.org/10.1016/j.envexpbot.2014.06.021

Einhardt, A. M., Ferreira, S., Hawerroth, C., Valadares, S. V. and Rodrigues, F. A. (2020a). Nickel potentiates soybean resistance against infection by Phakopsora pachyrhizi. Plant Pathology, 69, 849-859. https://doi.org/10.1111/ppa.13169

Einhardt, A. M., Ferreira, S., Oliveira, L. M., Ribeiro, D. M. and Rodrigues, F. A. (2020b). Glyphosate and nickel differently affect photosynthesis and ethylene in glyphosate resistant soybean plants infected by Phakopsora pachyrhizi. Physiologia Plantarum, 170, 592-606. https:// doi.org/10.1111/ppl.13195

Eskew, D. L., Welch, R. M. and Norvell, W. A. (1984). Nickel in Higher Plants: Further Evidence for an Essential Role. Plant Physiology, 76, 691-693. https://doi.org/10.1104/pp.76.3.691 
Fagundes-Nacarath, I. R. F., Debona, D. and Rodrigues, F. A. (2018). Oxalic acid-mediated biochemical and physiological changes in the common bean-Sclerotinia sclerotiorum interaction. Plant Physiology and Biochemistry, 129, 109-121. https://doi.org/10.1016/j. plaphy.2018.05.028

Freitas D. S., Rodak, B. W., Carneiro, M. A. C. and Guilherme, L. R. G. (2019). How does Ni fertilization affect a responsive soybean genotype? A dose study. Plant and Soil, 441, 567-586. https://doi.org/10.1007/s11104-019-04146-2

Gajewska, E. and Skłodowska, M. (2005). Antioxidative responses and proline level in leaves and roots of pea plants subjected to nickel stress. Acta Physiologiae Plantarum, 27, 329-340. https://doi.org/10.1007/s11738-005-0009-3

Gajewska, E. and Skłodowska, M. (2007). Effect of nickel on ROS content and antioxidative enzyme activities in wheat leaves. Biometals, 20, 27-36. https://doi.org/10.1007/s10534-006-9011-5

Gajewska, E., Skłodowska, M., Slaba, M. and Mazur, J. (2006). Effect of nickel on antioxidative enzyme activities, proline and chlorophyll content in wheat shoots. Biologia Plantarum, 50, 653-659. https://doi.org/10.1007/s10535-006-0102-5

Gerendás, J., Polacco, J. C., Freyermuth, S. K. and Sattelmacher, B. (1999). Significance of nickel for plant growth and metabolism. Journal of Plant Nutrition and Soil Science, 162, 241-256. https://doi.org/10.1002/(SICI)1522-2624(199906)162:3<241::AID-JPLN241>3.0.CO;2-Q

Gopal, R., Mishra, K. B., Zeeshan, M., Prasad, S. M. and Joshi, M. M. (2002). Laser-induced chlorophyll fluorescence spectra of mung plants growing under nickel stress. Current Science, 83, 880-884.

Hoagland, D. and Arnon, D. I. (1950). The water culture method for growing plants without soil. California Agricultural Experimental Station. Berkeley, USA.

Hodges, D. M., DeLong, J. M., Forney, C. F. and Prange, R. K. (1999). Improving the thiobarbituric acid-reactive-substances assay for estimating lipid peroxidation in plant tissues containing anthocyanin and other interfering compounds. Planta, 207, 604-611. https:// doi.org/10.1007/s004250050524

Huang, W., Tikkanen, M. and Zhang, S.-B. (2018). Photoinhibition of photosystem I in Nephrolepis falciformis depends on reactive oxygen species generated in the chloroplast stroma. Photosynthesis Research, 137,129-140. https://doi.org/10.1007/s11120-018-0484-1

Molas, J. (1997). Changes in morphological and anatomical structure of cabbage (Brassica oleracera L.) outer leaves and in ultrastructure of their chloroplasts caused by an in vitro excess of nickel. Photosynthetica, 34, 513-522. https://doi.org/10.1023/A:1006805327340

Molas, J. (2002). Changes of chloroplast ultrastructure and total chlorophyll concentration in cabbage leaves caused by excess of organic $\mathrm{Ni}(\mathrm{II})$ complexes. Environmental and Experimental Botany, 47, 115-126. https://doi.org/10.1016/S0098-8472(01)00116-2

Pavlovkin, J., Fiala, R., Čiamporová, M., Martinka, M. and Repka, V. (2016). Impact of nickel on grapevine (Vitis vinifera L.) root plasma membrane, ROS generation, and cell viability. Acta Botanica Croatica, 75, 25-30.

Rauser, W. E. and Dumbroff, E. B. (1981). Effects of excess cobalt, nickel and zinc on the water relations of Phaseolus vulgaris. Environmental and Experimental Botany, 21, 249-255. https://doi.org/10.1016/0098-8472(81)90032-0

Reis, A. R., Barcelos, J. P. Q., Osório, C. R. W. S., Santos, E. F., Lisboa, L. A. M., Santini, J. M. K., Santos, M. J. D., Furlani Junior, E., Campos, M., Figueiredo, P. A. M., Lavres, J. and Gratão, P. L. (2017). A glimpse into the physiological, biochemical and nutritional status of soybean plants under Ni-stress conditions. Environmental and Experimental Botany, 144, 76-87. https://doi.org/10.1016/j.envexpbot.2017.10.006

Rodríguez-Jiménez, T. J., Ojeda-Barrios, D. L., Blanco-Macías, F., Valdez-Cepeda, R. D. and Parra-Quezada, R. (2016). Urease and nickel in plant physiology. Revista Chapingo Serie Horticultura, 22, 69-81. https://doi.org/10.5154/r.rchsh.2014.11.051

Rucińska-Sobkowiak, R. (2016). Water relations in plants subjected to heavy metal stresses. Acta Physiologiae Plantarum, $38,257$. https://doi.org/10.1007/s11738-016-2277-5 
Santos, R. P., Cruz, A. C. F., larema, L., Kuki, K. N. and Otoni, W. C. (2008). Protocolo para extração de pigmentos foliares em portaenxertos de videira micropropagados. Ceres, 55, 356-364.

Somashekaraiah, B. V., Padmaja, K. and Prasad, A. R. K. (1992). Phytotoxicity of cadmium ions on germinating seedlings of mung bean (Phaseolus vulgaris): Involvement of lipid peroxides in chlorophyll degradation. Physiologia Plantarum, 85, 85-89. https://doi. org/10.1111/j.1399-3054.1992.tb05267.x

Stobart, A. K., Griffiths, W. T., Ameen-Bukhari, I. and Sherwood, R. P. (1985). The effect of Cd2+ on the biosynthesis of chlorophyll in leaves of barley. Physiologia Plantarum, 63, 293-298. https://doi.org/10.1111/j.1399-3054.1985.tb04268.x

Sumanta, N., Haque, C. I., Nishika, J. and Suprakash, R. (2014). Spectrophotometric analysis of chlorophylls and carotenoids from commonly grown fern species by using various extracting solvents. Research Journal of Chemical Sciences, 4, 63-69.

Szalontai, B., Horváth, L. I., Debreczeny, M., Droppa, M. and Horváth, G. (1999). Molecular rearrangements of thylakoids after heavy metal poisoning, as seen by Fourier transform infrared (FTIR) and electron spin resonance (ESR) spectroscopy. Photosynthesis Research, 61, 241-252. https://doi.org/10.1023/A:1006345523919

Yusuf, M., Fariduddin, Q., Hayat, S. and Ahmad, A. (2011). Nickel: An Overview of Uptake, Essentiality and Toxicity in Plants. Bulletin of Environmental Contamination and Toxicology, 86, 1-17. https://doi.org/10.1007/s00128-010-0171-1

Zasoski, R. J. and Burau, R. G. (1977). A rapid nitric-perchloric acid digestion method for multi-element tissue analysis. Communication of Soil Science and Plant Analysis, 8, 425-436. https://doi.org/10.1080/00103627709366735

Zhang, H., Zhang, F., Xia, Y., Wang, G. and Shen, Z. G. (2010). Excess copper induces production of hydrogen peroxide in the leaf of Elsholtzia haichowensis through apoplastic and symplastic CuZn-superoxide dismutase. Journal of Hazardous Materials, $178,834-843$. https://doi.org/10.1016/j.jhazmat.2010.02.014 